\title{
PROBLEMAS ATUAIS DA EXECUÇÃO PENAL *
}

RENÉ ARIEL DOTTI**

\section{SUMÁRIO}

$\S 10^{\circ}$ - A CRISE DA EXECUÇÃO PENAL. A - A manutenção de penas corporais. B - A execução em segredo de justiça. $C$ - A falência da pena pecuniária. D - A conservação de penas infamantes.

$\S 2 .^{\circ}$ - ALTERNATIVAS PARA A CRISE. A - As reformas estruturais. $B-A$ revisão do processo penal. $C$ - A revisão do panorama de ilicitudes. D - Medidas alternativas à prisão. $\mathrm{E}-\mathrm{A}$ autonomia do $\mathrm{Di}$ reito de Execução Penal.

\section{$\S 10^{\circ}-\mathrm{A}$ CRISE DA EXECUÇÃO PENAL}

\section{A. A MANUTENÇÃO DE PENAS CORPORAIS}

A profunda e extensa crise que domina o sistema de execução das penas e das medidas de segurança, constitui um dos mais graves problemas sociais dos dias presentes. Com as reiteradas denúncias sobre as violências praticadas no interior dos estabelecimentos penais, alguns organismos de classe como a Ordem dos Advogados do Brasil, a Comissão de Justiça e Paz e entidades defensoras dos direitos humanos do presidiário, estão rompendo as muralhas que convencionalmente pretendem dividir os territórios da liberdade e do confinamento.

São complexas e variadas as causas determinantes da crise, desde a falta de uma legislação adequada até a carência de re-

* Palestra proferida em 20 de abril de 1982 no I Encontro Nacional de Criminalistas, promovido pela Ordem dos Advogados do Brasil, Seção de São Paulo e Associação dos Advogados Criminais do Estado de São Paulo.

** Professor Titular na Universidade Federal do Paraná, Membro das Comissões elaboradoras dos anteprojetos da reforma da parte geral do Código e da Lei de Execução Penal. Advogado criminal. 
cursos humanos e materiais elementares para enfrentar os problemas da execução.

O Brasil conheceu, desde o tempo de seu descobrimento até que se completasse o período da dominação portuguesa, os regimes fantásticos de terror punitivo quando sobre o corpo do condenado se lançavam as expressões mais cruentas da violência dos homens e da ira dos deuses. As Ordenações Filipinas (1603) marcaram duránte dois séculos a face negra do Direito Penal. Hereges, apóstatas, feiticeiros, blasfemos, benzedores de cães e bichos sem autorização do Rei e tantos outros tipos pitorescos de autores eram submetidos às mais variadas formas de suplícios, com a execução das penas de morte ou de mutilação.

Correlatamente a uma tipologia de agentes marcada por ferro em brasa, existiam as categorias privilegiadas de sujeitos que gozavam de imunidade ou de especial tratamento punitivo. Assim os fidalgos, cavaleiros, escudeiros, desembargadores, etc.

O suplício, como os rituais do século XVIII o demonstram, foi um poderoso agente político. Como destaca FOUCAULT, "ele entra logicamente num sistema punitivo em que o soberano, de maneira direta ou indireta, exige, resolve e manda executar os castigos, na medida em que ele, através da lei, é atingido pelo crime. Em toda infração há um crimen majestatis, e no menor dos criminosos um pequeno regicida em potencial". ${ }^{1}$

A sentença que condenou Tiradentes pelo crime de lesa majestade determinou que com baraço e pregação fosse ele conduzido pelas ruas públicas ao lugar da forca para que "nella morra morte natural para sempre". A sepultura the foi negada porque a cabeça deveria ser cortada e levada a Villa Rica" aonde em o lugar mais público della será pregada, em um poste alto até que o tempo a consuma" e também "o seu corpo será dividido em quatro quartos e pregado em postes, pelo caminho de Minas no Sítio da Varginha e das Sebolas aonde o Réu teve as suas infames práticas, e os mais nos sítios de maiores povoações até que o tempo também os consuma"."2

A declaração de infâmia extensiva aos "seus filhos e netos tendo-os"; os bens aplicados para o Fisco e Câmara Real; a casa em que vivia em Villa Rica arrasada e salgada "para que

1. Michel Foucault - Vigiar e punir, Petrópolis, 1977, p. 49, 50.

2. Acórdão da relação da Alçada em 18 de abril de 1792 , em Autos de Devassa da Inconfidência Mineira, Rio de Janeiro, 1938, vol. VII, p. 145, 194 e 197. 
nunca mais no chão se edifique", além de outras cominações, completam o auto de terror que contém o episódio trágico da Inconfidência.

Mas a conversão da pena de morte em prisão perpétua constituiria a grande e generosa solução de indulgência que a defesa implorou à Rainha através dos recursos visando impedir a execução. No pedido de "segundos embargos de restituição do preso", o Advogado da Misericórdia José de Oliveira Fagundes afirmou "que o sincero arrependimento da offensa, a humilde deprecação do perdão, e a protestação da emenda sempre foram os últimos desejos e objetos do castigo e o maior sacrifício com que o delinqüente pode expiar o seu crime com satisfação da República, emenda dos costumes e fructo grande das Leis Criminaes; os RR. se acham penetrados de dôr que os não permittirá respirar muito tempo por verem a Soberania Offendida, e em termos de purgarem em um sanguinolento e funebre patíbulo as suas maledicências; elles sentem mais que a morte o escandalo que têm causado aos mais Vassallos, desejam dar provas do seu arrependimento ainda nas mais duras prisões, e nos degredos mais pestilentos, onde a impureza do ar, a corrupção dos alimentos Ihes façam viva guerra contra a conservação da pesada vida"."

A declaração formal de infâmia ou a danação da memória se o culpado morresse antes "de ser preso, acusado ou infamado", a amputação dos membros, açoites "com baraço e pregão", o degredo, as galés, a deserdação, o confisco, em suma; um repertório de medidas, mostrava as tormentosas preocupações de exemplaridade e retribuição. A execução da pena capital se procedia de três formas: $1 .^{\text {a }}$ morte cruel (a vida era lentamente tirada em meio a suplícios); 2 . $^{a}$ morte atroz (a eliminação era gravada com especiais circunstâncias, como a queima do cadáver, o esquartejamento, etc.); $3 .^{\circ}$ morte simples (limitada à supressão da vida sem rituais diversos e aplicada através da degolação ou do enforcamento, modalidade esta reservada às classes inferiores por traduzir uma forma de infamação). A morte civil era a perda dos direitos de cidadania e aparecia como previsão autônoma para algumas infrações ou como penas acessórias de outras cominações como a deportação, a relegação ou a prisão perpétua. ${ }^{4}$

3. Ob. cit. p. 216 .

4. Ver a propósito, AUGUSTO THOMPSON, Escorço histórico do direito criminal luso-brasileiro, São Paulo, 1976, p. 85. 
Numa concepção de pura ortodoxia, as penas corporais teriam sido banidas do nosso sistema. Para os efeitos puramente formais, as penas privativas de liberdade e as pecuniárias (como espécies principais) e a perda de função pública, as interdições de direitos e a publicação da sentença (como espécies acessórias) não se aplicam contra o corpo do condenado.

$\mathrm{Na}$ verdade, porém, a execução arbitrária e injusta das penas de reclusão e detenção e da chamada prisão simples, ${ }^{5}$ caracteriza situações claras de ofensas à integridade física ou à saúde do condenado, submetido não raro às mais dolorosas formas de maus tratos institucionalizados.

As flagrantes violações da intimidade do presidiário como de outros direitos da personalidade — constituem a porta aberta para a execução cruel da sanção penal que vai para muito além da perda da liberdade determinada na sentença. A negaęão ou o desconhecimento dos direitos do condenado, do preso provisório e dos destinatários das medidas de segurança, abre o caminho para a lapidação moral, produzindo os sentimentos de revolta ou acomodação da vítima e de indiferença ou de ódio da sociedade com relação às minorias que habitam o sistema penitenciário.

A falta de assistência em diversos níveis; a inexistência de programações eficientes e produtivas com vistas ao trabalho, sua justa remuneração e a correta aplicação dos frutos; e a ferocidade tradicional dos regimes de disciplina compõem não apenas a destruição moral e espiritual do delinqüente, mas também se estendem, como espetáculos de dor e sofrimento aos parentes e à própria sociedade. Na verdade, todo esse quadro de terror estimula a violência do carcereiro e dos demais funcionários do sistema e provoca as reações naturais de explosão a que se tem assistido, como as ocorrentes na Casa de Detenção de São Paulo. ${ }^{6}$

5. Segundo o Código Criminal do Império (1830) a pena de prisão simples deveria ser cumprida nas prisões públicas "que offerecerem maior comodidade e segurança e na maior proximidade possível dos lugares dos delictos” (art. 48). As origens de tal sanção e a prática atual de sua execução (misturando-se na vala comum os reclusos, os detentos e os presos simples) mostra o absurdo do regime de segregação massificada e alienante: quem comete um "crime" menor paga a nesma pena de um delito hediondo!

6. Os meios de comunicação e algumas entidades de classe como a Ordem dos Advogados do Brasil vêm, sistematicamente, denunciando o ambiente de insegurança individual e coletiva da Casa de Detenção. A superpopulação carcerária e a carência de meios materiais e humanos para o funcionamento de tal presídio constituem-se em permanentes fatores criminógenos neste calderão do inferno. 
As reiteradas lesões corporais; as várias formas de periclitação da vida e da saúde, despontando o crime de maus tratos; os assaltos sexuais e mais uma vasta gama de ofensas praticadas no curso da execução constituem alguns exemplos diários de verdadeiras penas corporais resultantes não somente da ação dos internos, como também, sob muitos aspectos, do abuso de autoridade.

\section{B. A EXECUÇÁO EM SEGREDO DE JUSTIÇA}

Em apropriada síntese, Calliess demonstra que tanto o Direito Penal como o direito positivo em geral constituem a estrutura dialogal de sistemas sociais e, por via de conseqüência, a pena deve ser concebida como um processo de diálogo entre o Estado e a Comunidade. ${ }^{7}$

Nos Estados sociais e democráticos de Direito, a pena deve cumprir, no dizer de Mir Puig, uma missão (política) de regulação ativa da vida social, que assegure seu funcionamento satisfatório, mediante a proteção dos bens dos cidadãos. ${ }^{8}$

Com esse ideal se harmoniza a tendência vitoriosa da Nonintervention, consistente na atualíssima orientação ${ }^{9}$ que está imprimindo variantes fecundas ao sistema ortodoxo da execução penal como um monopólio do Estado. O ceticismo frente às intervenções estatais em tal domínio tem se manifestado com grandes repercussões em face do seu caráter burocratizado e desumano. Daí então o empenho em abrir as portas da prisão, não somente para os chamados juízes paralelos (psiquiatras, psicólogos, funcionários especializados da administração, etc.), como também para a comunidade.

Analisando as alternativas para a crise do sistema carcerário, como objetivo estratégico à abolição da prisão (que é proposta radical), Juarez Cirino dos Santos refere "a extensão das medidas alternativas da pena e a abertura do cárcere para a sociedade. As formas alternativas da suspensão condicional da pena, do livramento condicional, dos regimes de semi-liber-

7. Cit. por Santiago Mir Puig, Introducción a las bases del Derecho Penal, Barcelona, Barcelona, 1975, p. 86.

8. Funcion de la pena y teoria del delito en nel Estado social y democratico de derecho, Barcelona, 1979, p. 25.

9. A designação dada a esse movimento crítico irradiado nos EUA procede da obra Radical Nonintervention do sociólogo Edwin M. 'Schur (cf. Hans Heinrich Jeschek, Tratado de Derecho Penal, parte geral, Barcelona, 1981, v. II, p. 1050) . 
dade, etc., são plenamente justificadas como táticas de aproximação do objetivo estratégico final. A abertura do cárcere para a sociedade limita as conseqüências da marginalização e desarticulação política do sistema carcerário, possibilitando a reintegração do condenado em sua classe (e na sociedade de classes), pela ação coordenada de associações de presos e de organização de trabalhadores (partidos políticos, sindicatos, comitês de fábricas, associações de bairros, etc.) transferindo o processo de ressocialização do Estado (prisão) para a comunidade (organizações de classes e populares)". ${ }^{10}$

O Anteprojeto de Lei de Execução Penal, viabilizando não somente as medidas alternativas à prisão, ${ }^{11}$ consagra entre os órgãos de execução o Patronato (que pode ser particular) e o Conselho da Comunidade. O primeiro destina-se a prestar assistência aos albergados e aos egressos. Incumbe-lhe também orientar os condenados à pena restritiva de direitos; a fiscalizar o cumprimento das penas de prestação de serviço à comunidade e de limitação de fim de semana; e de colaborar na fiscalização do cumprimento das condições da suspensão e do livramento condicional. ${ }^{12}$

Em cada comarca haverá um Conselho da Comunidade, composto, no mínimo, por um representante de associação comercial ou industrial, um advogado indicado pela seção da Ordem dos advogados do Brasil e um assistente social escolhido pela Delegacia Seccional do Conselho Nacional de Assistentes Sociais. Ao Conselho da Comunidade incumbe visitar, ao menos mensalmente, os estabelecimentos penais existentes na comarca; entrevistar presos; apresentar relatórios mensais ao juiz da execução e ao Conselho Penitenciário e diligenciar pela obtenção de recursos materiais e humanos para melhor assistência

10. A Criminologia Radical, Rio de Janeiro, 1981, p. 83,84

11. O fecundo tema das medidas penais alternativas à perda da liberdade, que ainda continua sendo a espinha-dorsal de todos os regimes modernos, já vem merecendo destaque em nossa literatura. Ver, especificamente, René Ariel Dotti, Bases e alternativas para o sistema de penas, Curitiba, 1980, p. 407 e s.; Heleno Cláudio Fragoso, "Alternativas da pena privativa de liberdade", em Revista de Direito Penal, n.० 29 de 1980 e Miguel Reale Júnior, "Penas Restritivas", em Ciência Penal n. 1 de 1981.

12. Cf. os arts. 77 e 78 do texto revisto. O Anteprojeto foi elaborado por Francisco de Assis Toledo, René Ariel Dotti, Benjamim Moraes Filho, Miguel Reale Júnior, Rogério Lauria Tucci, Ricardo Antunes Andreucci, Sérgio Marcos de Moraes Pitombo e Negi Calixto (DOU de 23-7-1981). A Comissão Revisora do diploma foi integrado pelos professores Francisco de Assis Toledo, René Ariel Dotti, Ricardo Antunes Andreucci e Jason Soares Albergaria e teve a colaboração destacada de Sergio Marcos de Moraes Pitombo e Everardo Cunha Luna. 
ao preso ou internado, em harmonia com a direção do estabelecimento. ${ }^{1: 3}$

Através da contribuição de tais órgãos junto aos demais encarregados da execução (Conselho Nacional de Política Criminal e Penitenciária, Juízo da Execução, Ministério Público, Conselho Penitenciário e os Departamentos Penitenciários), é possível se pensar em uma execução penal jurisdicionalizada, capaz de suprir as lacunas normativas responsáveis, na atualidade, pela erupção de fantásticas revoltas no condenado mundo dos cárceres. Trata-se, também, de eliminar o vazio legislativo existente no profundo território que separa os momentos da aplicação e execução das medidas penais.

A abertura das prisões à comunidade não se deve limitar aos presídios, mas atingir a todos os estabelecimentos penais, sejam eles destinados ao cumprimento da pena em meio cercado (penitenciárias, colônias industriais e agrícolas, hospital de custódia e tratamento ${ }^{14}$ ), como em meio livre (casa do albergado e locais reservados para tratamento ambulatorial, medida esta destinada ao semi-imputável segundo o artigo 98 do Anteprojeto (revisto) da lei de reforma à Parte Geral do Código Penal ${ }^{15}$ ).

Sob outra perspectiva, além dos direitos do preso (todos aqueles direitos não atingidos pela perda da liberdade) ${ }^{16}$ deve-se reconhecer o elenco de direitos do internado (segundo a sua condição pessoal), constando entre eles a liberdade de contratar médico de confiança pessoal a fim de orientar e acompanhar o tratamento. ${ }^{1 \tau}$

O reconhecimento formal dos direitos do internado aparece como um dos aspectos altamente vantajosos do sistema a constituir, a fim de se reduzir o clima de insegurança e de terror

13. Arts. 79 e 80 do Anteprojeto revisto.

14. Hospital de Custódia e Tratamento é a designação empregada pelos Anteprojetos (revistos) de reforma da parte geral do Código Penal e da Lei de Execuções Penais, em substituição ao Manicômio Judiciário do sistema vigente (arts. 98 a 100).

15. O Anteprojeto de lei reformando a parte geral do Código Penal, foi elaborado por Francisco de Assis Toledo, Francisco de Assis Serrano Neves, Ricardo Antunes Andreucci, Miguel Reale Júnior, Helio Fonseca, Rogerio Lauria Tucci e René Ariel Dotti. A propósito de sua discussão, ver Ricardo Antunes Andreucci, "Fundamentos de reforma penal", em Ciência Penal n. ${ }^{1}$ de 1981, além de outros autores na mesma revista. O Anteprojeto foi revisto por Francisco de Assis Toledo, Jair Leonardo Lopes e Miguel Reale Junior.

16. Cf. a especificação do Anteprojeto (revisto) da Lei de Execução Penal, art. 39 e s.

17. Cf. os arts. 41 e 42 do Anteprojeto (revisto) da Lei de Execução Penal. 
que adensam os manicômios judiciários em nosso País. As denúncias sobre a violação dos direitos humanos dos internados e de odiosas medidas de segurança perpétuas têm sido feitas corajosamente e com freqüência. ${ }^{18}$

A execução penal das medidas institucionais com a marginalização dos condenados, sacrifica o ideal de "recuperação social" - que é proclamado com otimismo em textos de Constituições e códigos penais modernos ${ }^{19}$ - e dificulta, cada vez mais, o processo de repersonalização da sociedade, compreendido através da esperança em ver a sociedade do amanhã meIhor configurada à medida da pessoa humana. Muitos infratores são infelizes herdeiros de uma sociedade desumana, coisificada e responsável pela descompensação que deságua no crime. ${ }^{20}$

A participação da comunidade no processo de execução penal, além da atuação de uma magistratura especializada em procedimentos nos quais efetivamente se movimentam os demais órgãos, é muito importante e extremamente necessária. A privação da liberdade não poderá ser executada em estabelecimentos caracterizados como instituições totais. Nas aludidas instituições vivem os sujeitos que: a) estão submetidos a uma só autoridade; b) em maior ou menor medida estão separados completamente do mundo circundante; c) em todos os processos vitais e nas necessidades dos internos, sofrem uma sujeição massificadora segundo um plano unicompressivo (regulamento interno); d) entregam-se porque o sistema reclama para si a pessoa total do interno, e perdem a separação usual do âmbito de trabalho, do lazer e do descanso. ${ }^{21}$

18. Em seu livro $A$ revolução dos loucos, São Paulo, 1980, o jornalista Percival de Souza promoveu um grande levantamento no manicômio judiciário de São Paulo. A estatística e a documentação impressionam quanto à tragédia e ao abandono dos infelizes habitantes do sistema.

19. Constituições da Itália (1947, art. 27, n.० 3); Espanha (1978, art. 25, n. 2); e códigos penais (Brasil, 1969) art. 37; Suíça, 1937, art. 37 e Rússia, 1960, art. 20).

20. A designação para o fenômeno da repersonalização da sociedade e a doutrina indicada no texto são de Antonio Beristain, "La cárcel como factor de configuracion social" artigo publicado em Doctrina Penal, Buenos Aires, n.0 2, 1978, p. 290.

21. Sobre o assunto, Hilde Kaufmann, Ejecución penal y terapia social, Buenos Aires, 1979. p. 70 e s. As instituições totais podem ser divididas em cinco grupos: 1.0 - estabelecimentos para o cuidado de pessoas incapazes (cegos, velhos e órfáos) ou pobres (asilos); $20^{\circ}$ - estabelecimentos para portadores de doenças contagiosas (tuberculose, lepra); 3.0 - estabelecimento para abrigar as pessoas, não no seu interesse, mas da sociedade em face do perigo que sua liberdade representa (presos e internados); 4.0 - instituições que acreditam poder realizar melhores tarefas similares ao trabalho (bases coloniais, 
A exclusão dos estabelecimentos penais do repertório das instituições totais será um passo decisivo para que a execução deixe de ser - na apropriada imagem de FOUCAULT — um espetáculo revelador de "um estranho segredo entre a Justiça e o condenado". ${ }^{22}$

\section{A FALÊNCIA DA PENA PECUNIÁRIA}

Entre os pontos altos da crise da execução penal se pode destacar a falência da pena pecuniária. Estabelecida em quantidades rígidas no Código Penal e na quase totalidade das leis especiais, a multa não exerce os efeitos elementares de retribuição e de prevenção que devem informar todas as penas.

Ao publicar o seu Tratado em meados de 1960, José Frederico Marques já lamentava a frustração da multa cơmo reação penal em face da desvalorização da moeda. ${ }^{23}$

$\mathrm{Na}$ intenção de fazer com que a pena de multa acompanhasse a inflação, a Lei $n .{ }^{\circ} 6.416 / 77$ determinou o reajuste para o padrão cruzeiros, na proporção de 1:2.000 (um por dois mil) dos valores monetários previstos pelos Códigos Penal e de Processo Penal e pela Lei das Contravenções Penais (art. $4^{\circ}$ ). Mas tal "atualização" não se promoveu na legislação extravagante, abrindo grave lacuna no ordenamento positivo.

O Código Eleitoral (Lei n. 4.737 de 15-7-1965), o Código Penal de 1969 e a lei anti-tóxico (Lei n. 6.368 de 21-10-1976) estabeleceram o sistema de dias-multa. Assim também o fez o Anteprojeto de reforma da parte geral do Código Penal (1981). $\mathrm{Na}$ preocupação de emprestar às sanções pecuniárias um caráter mais adequado aos objetivos da retribuição e da prevenção social, o Anteprojeto previu a multa-reparatória, ou seja, uma sanção reversível em favor da vítima do delito (art. 53). Nos trabalhos de revisão, porém, a inovação foi abolida, conservando-se apenas um tipo de sanção pecuniária: a multa (arts. 32, II e 49 e s.). O seu valor será, no mínimo, de dez, e, no máximo, de trezentos e sessenta dias-multa, o qual não poderá ser inferior ao um trigésimo do maior salário mínimo mensal vigente ao tempo do fato, nem superior a cinco vezes esse salário. $\mathrm{Na}$

grandes fazendas, regimentos); 5.0 - lugares de isolamento do mundo e de instrução religiosa (conventos, monastérios, etc.); (cf. Ervin Goffman, em Kaufmann. ob. cit. p. 71).

22. Ob. cit. p. 20.

23. Tratado de Direito Penal, São Paulo, 1966. v. III, p. 142. 
execução, o valor da multa será atualizado pelos índices de correção monetária (art. $49, \S \S 1 .^{\circ}$ e $2^{\circ}$ ). Muito importante é a previsão específica do destino da multa: ela reverterá ao fundo penitenciário. A Reforma penal e penitenciária de 1977 não alterou o artigo 35 do Código que ainda afirma: "A pena de multa consiste no pagamento, em selo penitenciário, da quantia fixada na sentença".

Porém, o selo penitenciário desapareceu quando o DecretoLei n. 34 de 18 de novembro de 1966, através do artigo 14, inciso IV, revogou o Decreto $n .{ }^{\circ} 1.726$ de 1 de novembro de 1939. Este diploma regulava o Decreto n. 24.797 de 14 de julho de 1934.

Não existe atualmente em nosso País uma política econômico-financeira especificamente dedicada à questão das prisões. Com a abolição do selo penitenciário, a multa é recolhida aos cofnes públicos ou recebida pelos escrivães que a depositam em instituições bancárias. ${ }^{24}$ Mas não há retorno para cumprir os fins previstos pela sanção. Aliás, para se avaliar o pouco apreço dedicado por alguns setores influentes do Poder ao sistema penal e penitenciário, basta atentar para o seguinte fato: o selo penitenciário desapareceu através de um decreto cuja Súmula é esta: "Dispõe sobre nova denominação do Imposto de Consumo, altera a Lei n. 4.502 , de 30 de novembro de 1964 , extingüe diversas taxas e dá outras providências". O artigo 14 (que através do inciso IV aboliu o selo penitenciário), declara: "Fica extinta a cobrança dos seguintes tributos" (sic).

A multa, que consiste no pagamento em selo penitenciário da quantia fixada na sentença (CP art. 25), passou a ser, na linguagem desse "legislador" um simples... "tributo".

\section{A CONSERVAÇÃO DE PENAS INFAMANTES}

Entre as penas acessórias encontram-se claros resíduos das penas infamantes. Se é certo que tanto a doutrina como a jurisprudência procurem (compreensivelmente) ignorar ou rejeitar este reconhecimento, não se pode negar que a publicação da sentença é medida de natureza medularmente infamatória. Também algumas interdições de direitos têm a marca da desonra, como ocorre com a inabilitação para o exercício do pátrio poder, tutela ou curatela, que não admite a reabilitação. É perpétua, como

24. A oportuna observação é de Celso Delmanto, Código Penal, São Paulo, 1980, p. 28. 
também perpétua é a pena acessória da perda de função pública.

Corrigindo tais injustiças, o Anteprojeto que reforma a parte geral do Código Penal dispõe que a reabilitação alcança quaisquer penas e também os efeitos da condenação (como tais considerados a perda do cargo, da função pública ou mandato eletivo e a incapacidade para o exercício do pátrio poder, tutela ou curatela nos crimes dolosos sujeitos a reclusão, cometidos contra filho, tutelado ou curatelado, art. 93 e parágrafo único e 92, I e II). Nos casos acima especificados, é vedada, no entanto, a reintegração na situação anterior, isto é, o servidor público não poderá retornar ao mesmo cargo; o mandatário eletivo não recupera o mandato perdido; e o pai, o tutor e o curador não mais exercerão os poderes respectivos sobre a mesma pessoa. Mas assim será possível em relação a outros filhos, tutelados ou curatelados, bem como o servidor público poderá - após reabilitado - ser admitido a exercer função pública distinta daquela exercida ao tempo do fato que gerou a condenação. O deputado que perdeu o mandato poderá, após a reabilitação, concorrer a outro cargo eleitoral.

Reparando antiga e injusta prática, o Anteprojeto reduz para dois anos o prazo para requerer a reabilitação. Além disso, atualizou o instituto com a realidade social e humana. ${ }^{25}$

\section{$\S 2 .^{\circ}-$ ALTERNATIVAS PARA A CRISE}

\section{A. AS REFORMAS ESTRUTURAIS}

A crise da execução das penas e das medidas de segurança é um fenômeno global, que não pode ser atacado somente pela revisão das estruturas formais de controle da criminalidade.

As manifestações de violência institucionalizada aos direitos do preso e do internado mostram a atualidade da proposta de comutação da pena de morte pelo encarceramento, feita pelo Advogado da Misericórdia José de Oliveira Fagundes há cento e noventa anos atrás. Quase dois séculos! ("nos degredos mais pestilentos, onde a impureza do ar, a corrupção dos alimentos Ihes façam viva guerra contra a conservação da pesada vida").

25. A propósito da morte e da ressurreição do instituto, merece leitura o peregrino trabalho de Jair Leonardo Lopes, Da Reabilitaçâo no Direito Penal, Belo Horizonte, 1956. 
A necessidade em se investigar amplamente em nosso País o estado das prisões tem sido revelado de maneira candente. Vale como referência fundamental o trabalho da Comissão Parlamentar de Inquérito destinada a apurar a situação penitenciária nacional e que contém um volumoso conjunto de depoimentos e documentação. ${ }^{26}$

A grande síntese do pensamento de reforma consiste no reconhecimento de que, nos últimos trinta anos, a doutrina penal superestimou a importância dos conceitos formais em torno do delito, do delinqüente e das reações penais, afastando-se, porém, da realidade da vida e esquecendo-se da necessidade de proceder, periodicamente, à revisão crítica dos institutos. $\mathrm{O}$ problema da exaustão da dogmática - com os preciosismos de linguagem e de perspectivas - foi muito bem ilustrada por JuanRamon Capella: "Fala-se, além das normas jurídicas, em relações, situações, instituições e estatutos jurídicos. A ontologia teorética da ciência jurídica aparece assim curiosamente duplicada, triplicada ou quintuplicada, sendo seguramente a isto que Jhering se referia quando falava da mania que os juristas têm para cortar os cabelos em sete partes. O estudante de Direito é obrigado a deter-se a averiguar a raiz da distinção entre "relação jurídica" e "situação jurídica" em qualquer pandectista alemão, divertimento capaz de absorver o espírito como a leitura de livros da cavalaria, com a perigosa diferença de que tal investigação é exigida para a aprendizagem da matéria". ${ }^{27}$

Assim, a primeira iniciativa para o combate à crise da execução deve estar ligada diretamente à revisão dos mecanismos materiais de aplicação das normas penais em seu amplo sentido (compreendendo desde os textos de Direito Penal, de Processo Penal, de Direito Administrativo), a fim de que a justiça criminal se constitua num serviço público de primeira necessidade e não o campo de concentração onde o desespero dos litigantes; a aflição dos juízes (à imagem de Sísifo) empurrando o processo tribunal acima); a peregrinação monótona dos oficiais de justiça, como novos e velhos carontes; ${ }^{28}$ a surpresa das testemunhas e dos demais envolvidos com o processo (a verem o bar-

26. Presidida pelo Deputado José Bonifácio Neto, a CPI teve como relator o Deputado Ibrahim Abi-Ackel (DCN, supl, ao n. 61 de 4-6-1976).

27. A extinção do direito e a supressão dos juristas, Coimbra, 1977, p. 30.

28. Segundo a mitologia, Caronte era o barqueiro dos Infernos que passava de uma para outra margem do rio os condenados. "Numa barca surgiu, direito a nós. um velho de cabelos que o tempo embranquecera" (Dante, A divina comédia - o inferno, Canto III) . 
roquismo das técnicas de colheitas de prova); a neurose dos escrivães com os inúmeros carimbos, termos, datas, conclusões e as embalagens das cartas precatórias; tudo isso compõe um mural de sofrimento, num País em que a burocracia é tão forte que chegou a criar um... Ministério. ${ }^{29}$

Entre as reformas de estruturas para a melhor administração da Justiça criminal, como uma das providências para atenuar a crise, destacam-se: $1^{\circ}$ ) a reorganização do Poder Judiciário em bases de independência institucional e econômica; $2^{\circ}$ ) a reestrutura do Ministério Público que deve, efetivamente, cumprir o seu papel histórico de zelar pelos interesses da sociedade e assumir o comando, não apenas da ação penal, como também da investigação que a deverá instruir; $3^{\circ}$ ) a reestrutura da Polícia Judiciária, eliminando-se a grave disputa de atribuições entre as polícias militares e civis no campo da investigação, prevenção e repressão dos ilícitos penais. Além disso, a Polícia Judiciária deve ser um Poder Civil e seus quadros providos mediante concurso de provas e títulos nos quais se evidencie o aperfeiçoamento científico da instituição; $4 .^{\circ}$ ) a participação do povo nas reformas das leis penais, de processo penal, de organização judiciária, etc., na medida em que os diplomas constituam, realmente, a expressão da vontade da maioria, colhida no processo legislativo segundo o modelo democrático dos parlamentos de Direito; $5^{\circ}$ ) melhores critérios didáticos dentro de uma concepção realmente universalista e humanista das universidades, para a formação dos juristas e profissionais do $\mathrm{Di}$ reito; $6 .^{\circ}$ ) a melhor difusão através dos meios de comunicação dos problemas críticos do direito, da lei, e da justiça, a fim de melhor sensibilizar a comunidade em setores importantes de sua representação.

\section{B. A REVISÃO dO PROCESSO PENAL}

As categorias dogmáticas do processo penal não devem perder o contato com os valores que o processo deve proteger. E para se evitar um formalismo estéril, é necessário - como diz Bettiol - que o estudo do processo penal tenha todo o cuidado

29. Em fins de 1980 realizou-se em Porto Alegre o I Congresso Brasileiro para a Desburocratização da Justiça em promoção ao Movimento Gaucho de Advogados. Juizados de instrução para os delitos de circulação, uso do correto para intimações de testemunhas residentes na comarca do processo e maior presteza na colheita da prova foram algumas das sugestöes encaminhadas ao Ministro Helio Beltrão. 
em não transplantar para a sua compreensão os conceitos ou os esquemas e institutos elaborados no seio da ciência do processo como disciplina unitária, com aspirações de validade tanto para o processo civil como para o processo penal, dado que os dois ordenamentos em questão - à parte a sua terminologia — têm bem pouco de comum ${ }^{30}$.

Além do sentido pragmático de sua economia interna, o processo penal deve ser a expressão das liberdades públicas e dos direitos e garantias individuais, valendo a advertência de Eberhard Schmid segundo a qual "as ideologias políticas e as palavras engenhosas em nenhuma matéria são tão perigosas como no direito processual penal" $"$.

Como já acentuamos a propósito do assunto, "um regime político guiado pelos parâmetros de um Estado social e democrático de Direito deve orientar a sua reforma do sistema de sanções e qualquer outra, em sólidas bases de segurança individual. A obediência rigorosa a este valor implica na proteção dos direitos do Homem no Processo Penal" 32.

Com muita ênfase, Mario Valiante sustenta que o respeito dos direitos humanos é indispensável para o progresso material, intelectual e moral, bem como para o desenvolvimento das pessoas e da sociedade em atenção ao bem comum ${ }^{33}$.

\section{A REVISÃO DO PANORAMA DE ILICITUDES}

A arquitetura dos ilícitos penais passa atualmente por profunda revisão crítica. As tendências de descriminalização, criminalização, neo-criminalização e despenalização constituem temas obrigatórios das agendas de vários congressos internalcionais e internos, a exemplo do que ocorreu em Budapeste (1974), com o XI Congresso Internacional de Direito Penal, e em Curitiba (1978), através do Simpósio promovido pelo Instituto Brasileiro de Ciências Penais.

O processo de descriminalização reverterá em favor do aprimoramento do direito positivo quando muitas espécies de ilicitudes devem ser eliminadas (alguns crimes contra os cos-

30. Instituzioni di diritto e procedura penale, Pádua, 1966, p. 221.

31. Los fundamentos teoricos y constitucionaies del derecho procesal penal, Buenos Aires, 1957, p. 190.

32. Ob. cit. p. 140 .

33. Il nuovo processo penale, Milão, 1975, p. 30. 
tumes e contra a Administração Pública podem ser desde logo referidos).

É curial que a descriminalização pressupõe uma tarefa prévia: a consolidação das leis extravagantes a fim de se erradicar (ou atenuar) o sério problema da inflação legislativa.

As hipóteses de destipificação e despenalização aparecem atualmente como providências necessárias para descongestionar a administração da Justiça Criminal, que não mais suporta a carga excessiva dos feitos, muitos deles de menor interesse para os objetivos de uma Política Criminal moderna e eficiente.

A destipificação consiste no processo legislativo pelo qual se declaram lícitas certas condutas anteriormente proibidas pelo Direito Penal. E a despenalização implica, também pela via legislativa, em submeter determinados fatos ilícitos à jurisdição de outros ramos jurídicos que não o Direito Penal. As penas criminais são substituídas por sanções de outra natureza. Esta solução é muito oportuna no quadro dos delitos sem vítimas especialmente ofendidas, nos conflitos inter-familiares e na delinqüência juvenil ${ }^{34}$. Em concepção mais restrita, despenalizar significa excluir ou reduzir a incidência das penas privativas de liberdade.

\section{MEDIDAS ALTERnATIVAS À PRISÃO}

Embora se conserve como o centro de gravidade dos sistemas penais de todo o mundo, a pena privativa de liberdade constitui a face mais visível da execução do Direito Penal e também fonte dos graves males acarretados quando a sua execução é arbitrária e ofensora dos direitos do condenado ou do internado.

Diante do reconhecimento universal da crise das penas institucionais, os projetos e códigos dos anos 70 vêm consagrando a previsão de outras sanções que, embora possam recortar a liberdade do condenado, não o afastam da comunidade e, conseqüentemente, de participar do processo de desenvolvimento da sociedade. A prisão é reservada para as espécies mais graves de ilicitude ou, em outra hipótese, quando o exame dos antecedentes, a personalidade e a conduta social do agente recomendarem tal providência.

34. Antonio Beristain, Crisis del Derecho Represivo, Madrid, 1977, p. 58. 
A prisão, porém, não deve ser executado em holocausto aos direitos e às garantias do condenado ou do internado. Por outro lado, não deve ser contínua, isto é, cumprida de maneira total, como forma pura e simples de encarceramento.

Os regimes fechados, semi-aberto e aberto, adotados pelos projetos de reforma do sistema criminal brasileiro, constituem etapas importantes para a execução descontínua da privação da liberdade: começando pelo regime fechado, o condenado vai, progressivamente, alcançando as etapas posteriores. Assim, por exemplo, da penitenciária para a colônia agrícola e para a prisãoalbergue.

Existe em tal procedimento um retorno gradual à comunidade mediante o cumprimento de condições (satisfação de parte da pena no regime anterior e o mérito do preso indicando a progressão).

Como medidas detentivas de caráter alternativo às penas privativas de liberdade, podem ser mencionadas a prisão domiciliar ${ }^{35}$, a prisão-albergue, a prisão de fim de semana ${ }^{36}$ e a prisão descontínua ${ }^{37}$.

As medidas não detentivas podem classificar-se em: a) limitativas de liberdade; b) limitativas de capacidade jurídica; c) pecuniárias; d) providências éticas; e e) exclusão da jurisdição penal.

As primeiras modalidades admitem as seguintes hipóteses: 1. ${ }^{2}$ proibição de frequentar determinados lugares; $2 .^{a}$ liberdade vigiada; $3 .^{a}$ trabalho gratuito em favor da comunidade; $4 .^{a}$ suspensão condicional da pena; $5 .^{a}$ regime de prova; $6{ }^{a}$ livramento condicional; $7 .^{\mathrm{a}}$ parole.

35. Em nosso sistema, a prisão domiciliar tem natureza estritamente processual (CPP art. 295 e Lei n. 5.256/67), não se constituindo em sanção penal, salvo excepcionalmente como forma convertida da prisão-albergue. Em tal sentido existem precedentes na jurisprudência de tribunais de São Paulo. No sistema argentino, quando a pena é inferior a seis meses de prisão, podem ser detidas em suas próprias casas as mulheres honestas e as pessoas maiores de sessenta anos ou valetudinárias (CP art. 10) .

36. A prisão de fim de semana foi adotada pelo recente projeto de Código Penal espanhol (1980, conforme os artigos 38 a 42 ).

37. Nesta modalidade de execução, o condenado recolhe-se parte do dia ao estabelecimento penal. O período é variável e poderá também recair em noites ou dias de fim de semana. Năo existe um programa previamente determinado de recolhimento, o qual terá características iguais aos dos presos ordinários (cf. L. J. d'Anjou, "Alternatives Sanctions", trabalho publicado em International Summaries, Departamento de Justiça dos EUA, 1978, v. 2, p. 180) . 
As penas que restringem a capacidade jurídica, podem as-

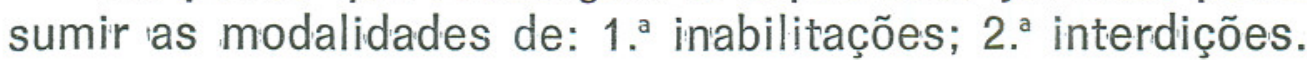

As sanções pecuniárias consistem: $1 .^{\mathrm{a}}$ na multa; $2 .^{\mathrm{a}}$ no confisco; $3 .^{a}$ na indenização ao ofendido; e $4 .^{a}$ na reparação simbólica.

As chamadas providências éticas traduzem-se: $1 .^{\text {a }}$ na admoestação; $2 .^{a}$ na retratação; $3 .^{a}$ no pendão judicial.

Finalmente, as alternativas à jurisdição penal podem se revestir nas formas de: $1 .^{\text {a }}$ suspensão do procedimento; e $2 .^{\text {a }}$ extinção do procedimento ${ }^{38}$.

Como se poderá verificar existe uma vasta gama de reações anti-criminais que, no dizer sempre autorizado de Eduardo Correia, atuam "sem deixar de reprovar, reeducam, ressocializam e recuperam os delinqüentes, impedindo realmente a reincidência" 39 de modo a se aplicar uma penologia diferenciada que possa servir ao Direito Criminal Moderno. E isso é feito sem enfraquecer a idéia de repressão que não pode mais continuar somente ligada ao lado físico da sanção.

\section{E. A AUTONOMIA DO DIREITO DE EXECUÇÃO PENAL}

O regime de legalidade que deve iluminar todo o processo de execução penal jamais poderá ser eqüível enquanto o sistema não contar com uma legislação própria e que confira autonomia ao Direito de Execução Penal, compreendido como "o conjunto de normas jurídicas relativas à execução das penas e das medidas de segurança" 40.

O princípio da legalidade na execução constitui um desdobramento lógico do princípio da anterioridade dos delitos e das penas, tão caro às tradições democráticas do Direito Penal liberal. A execução das penas em geral não pode ficar submetida ao poder de arbitrio do diretor, dos funcionários e dos carcereiros das instituições penitenciárias, como se a intervenção do

38. A enumeração e a análise das medidas alternativas à pena de prisão de feitío clássico é procedida em nosso livro Bases e alternativas para o sistema de penas, cit. p. 407 e s. O Anteprojeto (revisto) de reforma da parte geral do Código Penal aboliu a categoria das penas acessórias e estabeleceu como alternativas à pena privativa de liberdade as seguintes sançōes: $1 .^{\mathrm{a}}$ - prisão albergue; $2 .^{a}$ - prestação de serviços à comunidade; 3.a - interdição temporária de direitos; e 4.a - limitação de fim de semana (arts. 32, 33 e 43).

39. Direito criminal, Coimbra, 1971, v. II, p. 419 e s.

40. Cuello Calón, Derecho Penal, Barcelona, 1971, v. II, t. I, p. 773. 
juiz, do Ministério Público e de outros órgãos fosse algo de alheio aos costumes e aos hábitos do estabelecimento.

Um diploma regulador para atender o complexo universo da execução, constitui obra urgente do Estado. Os temas atinentes à classificação e assistência aos condenados, aos presos provisórios e aos internados; os problemas referentes ao trabalho (que deve perder a mancha da escravatura), aos direitos, aos deveres e à disciplina; a concepção e o funcionamento dos órgãos de execução e dos estabelecimentos; os princípios e as regras da execução das penas e das medidas de segurança em espécie; os princípios e as regras sobre o procedimento judicial, etc., devem ser minuciosamente regulados para se conferir dignidade científica à nova disciplina e demarcar os limites de atuação dos diversos órgãos e do próprio sentenciado, que não poderá viver à margem ou passivamente aos movimentos do sistema.

As famosas normas gerais do regime penitenciário, caracterizadas na Lei n. 3.274 de 2 de outubro de 1957, não constituem, na verdade, normas jurídicas posto carecerem de eficácia. Não existem sanções para o descumprimento dos princípios e das regras que contém o diploma.

Ao fracasso vintenário da Lei $n .03 .274$ seguiu-se, recentemente, a frustração gerada pela Lei n. ${ }^{\circ} 6.416$ de 24 de maio de 1977 na parte em que deferiu à lei local ou, na sua falta, ao Conselho Superior da Magistratura ou órgão equivalente, o poder para regulamentar "concessões", como os regimes de execução; prisão-albergue; as permissões de saída; as saídas temporárias; o trabalho externo; a freqüência a curso profissionalizante, etc. (CP art. $30 \S 6{ }^{\circ}$ ). A situação atual é caótica. Raríssimas são as unidades federativas (São Paulo, Minas Gerais, por exemplo) que legislaram complementarmente. $\mathrm{Na}$ quase totalidade dos Estados e Territórios, as chamadas concessões estão sendo deferidas e administradas sem critérios adequados e uniformes. E em muitos lugares simplesmente não estão sendo reconhecidas.

Por isso tudo, é oportuna a lembrança do Relatório da CPI do sistema penitenciário $(1975,1976)$ quando o seu autor acentuou que a doutrina evoluiu no sentido da constitucionalidade de um diploma regulador da execução, alijando, assim, argumentos impugnadores da iniciativa da União para elaborar um Código de Execuções Penais. Textualmente salientou o Deputado Ibrahim Abi-Ackel: "Com efeito, se a etapa de cumprimento 
das penas ou medidas de segurança não se dissociam do Direito Penal, sendo, ao contrário, o esteio central do seu sistema, não há como sustentar a idéia de um Código Penal unitário e leis de regulamento regionais de execução penal. Uma lei específica e abrangente atenderá todos os problemas relacionados com a execução penal, equacionando matérias pertinentes aos organismos administrativos, à intervenção jurisdicional e, sobretudo, ao tratamento penal em suas diversas fases e estágios, demarcando, assim, os limites penais de segurança. Retirará, em suma, a execução penal do hiato de legalidade em que se encontra" ${ }^{41}$. 